\title{
Application of Islamic Work Ethics to Employees at PT Asuransi Takaful Umum (Case Study: Head Office Jakarta)
}

\author{
Lulu Lathifan $^{1 *}$, Nurfahmiyati ${ }^{2}$, Meidy Haviz $^{3}$ \\ $\left.{ }^{1}, 2,3\right)$ Universitas Islam Bandung, Jl. Tamansari No. 1 Bandung \\ * Corresponding Author Email:lululathifan22@gmail.com
}

Received: 13/09/2020

Accepted: 29/09/2020

Keywords: Islamic Work Ethics, Employees, Leaders, Takaful Insurance

\begin{abstract}
Work is natural and at the same time one of the human identities, so that work based on the principles of faith and tawhid, not only shows the nature of a Muslim but also elevates the dignity as a servant of Allah SWT. PT Asuransi Takaful Umum was founded by law that is based on the Al - Qur'an and Hadith, as well as the Law with the applicable regulations. The research method used to support this research is quantitative research. Accompanied by the use of observation and interview methods as well as library engineering research methods. The number of respondents used in this study was 50 employees with 10 of them being leaders. This research is also calculated using the Likert scale as the calculation tool used so that the variables are translated into variable indicators and then these variable indicators are used to become a reference for preparing questions. Respondents will determine their level of agreement with the questions asked by selecting the questions that have been provided. The results showed that PT Asuransi Takaful Umum has implemented Islamic work ethics by existing regulations in the company. The application of Islamic work ethics is seen from the 5 dimensions used, namely Itqan, Hafidzun Alim, Amanah, Al-Kayis, Al-Qawiy, and has been implemented. With a conducive working atmosphere, the relationship between employees and directors is carried out well so that unwanted things can be controlled.
\end{abstract}

\section{INTRODUCTION}

Islam is a religion that upholds the value of work. In the Islamic view, work is worship and a way to get closer to Allah SWT. Work is natural and at the same time one of the human identities, so that work based on the principles of faith and monotheism, not only shows the nature of a Muslim but also elevates the dignity of being a servant of Allah. If work is human nature, then it is clear that humans are reluctant to work, lazy, and do not want to use their full potential to express faith in the form of creative deeds (Tasmara, 1995). Work ethics can be interpreted as values or habits that must be carried out by a person while in the work environment. Rasulullah SAW was used as a role model by Muslims because of his very noble character and character. This is following the word of Allah SWT which is written in the Qur'an in Surah Al-Ahzab verse 21. In the Islamic view, work is an inseparable unity, starting from the intention to work, which is not only seeking the abundance of material in the world but also looking for a reward to be respected later. This intention will correlate with the efforts made by an individual (Amaliah et al. 2013). Islam does not only tell its people to work hard without being followed by various safeguards in the form of moral values, namely morals or ethics. This morality can deliver various professions safely to their goal of sincere worship(Hidayat, 2006). When someone understands religious values at work, this will be reflected in their behavior at work and make an individual who has the best performance achievement. In its work as the first General Sharia Insurance in Indonesia, PT Asuransi Takaful Umum has had experience in its field for approximately 20 years with branch offices spread across Indonesia. It is proven by the abundance of experience PT Asuransi Takaful Umum has a very good corporate financial health with a very large solvency ratio. Where the solvency ratio is an ability to fulfill obligations to its customers or as a company's ability to meet insurance claims coverage submitted by customers. Regarding the financial statements in 2020, PT Asuransi Takaful Umum is proven to have a company fund solvency ratio of $2028 \%$ and higher than the government provisions contained in financial Services Authority Regulation Number 72 / Pojk.05/2016 concerning the Financial Health of Insurance Companies and Reinsurance Companies with Sharia Principles. The Government has determined that the Solvency Ratio of an Insurance Company is required to have a minimum of $120 \%$ of company funds. PT Asuransi Takaful Umum also has a solvency ratio of tabarru 'and land funds of 836 billion and total assets of 62 billion. 


\section{LITERATURE REVIEW}

Ethics comes from Greek, namely, ethos, which means something that is believed, how to act, attitudes, and perceptions of work values. From this word was born what is called ethics, namely guidelines, morals, and behavior or also known as etiquette which means polite manner (Tasmara, 1995). Whereas work is all dynamic activities and has the goal of fulfilling certain needs (physical and spiritual), and in achieving these goals he tries with full sincerity to achieve optimal performance as proof of his dedication to Allah SWT (Tasmara, 1995). According to Tasmara (1995) states that work ethic is his personality and a way of expressing, seeing, believing, and giving meaning to something, which encourages him to act and achieve optimal charity. Many factors can affect a person's work ethic. Islamic work ethic is essentially part of the Islamic concept of humans because work ethics is part of the process of human existence in a very broad and complex field of life. Work ethics are the values that shape a person's personality at work. Work ethics are essentially shaped and influenced by the value system that a person adopts at work. Which then forms a spirit that differentiates it from one another. Thus, Islamic work ethics is a personal reflection of a Khalifah who works based on his conceptual abilities who are creative and innovative (Azizi, 2005). Islamic work ethic is essentially part of the Islamic concept of humans because work ethics is part of the process of human existence in a very broad and complex field of life. Work ethics are the values that shape a person's personality at work. Work ethics are essentially shaped and influenced by the value system that a person adopts at work. Which then forms a spirit that differentiates it from one another. Thus, Islamic work ethics is a personal reflection of a Khalifah who works based on his conceptual abilities who are creative and innovative (Azizi, 2005). Islamic work ethic is essentially part of the Islamic concept of humans because work ethics is part of the process of human existence in a very broad and complex field of life. Work ethics are the values that shape a person's personality at work. Work ethics are essentially shaped and influenced by the value system that a person adopts at work. Which then forms a spirit that differentiates it from one another. Thus, Islamic work ethics is a personal reflection of a Khalifah who works based on his conceptual abilities who are creative and innovative (Azizi, 2005). work ethic is part of the process of human existence in a very broad and complex field of life. Work ethics are the values that shape a person's personality at work. Work ethics are essentially shaped and influenced by the value system that a person adheres to at work. Which then forms a spirit that differentiates it from one another. Thus, Islamic work ethics is a personal reflection of a Khalifah who works based on his conceptual abilities who are creative and innovative (Azizi, 2005). work ethic is part of the process of human existence in a very broad and complex field of life. Work ethics are the values that shape a person's personality at work. Work ethics are essentially shaped and influenced by the value system that a person adopts at work. Which then forms a spirit that differentiates it from one another. Thus, Islamic work ethics is a personal reflection of a Khalifah who works based on his conceptual abilities who are creative and innovative (Azizi, 2005). Which then forms a spirit that differentiates it from one another. Thus, Islamic work ethics is a personal reflection of a Khalifah who works based on his conceptual abilities who are creative and innovative (Azizi, 2005). Which then forms a spirit that differentiates it from one another. Thus, Islamic work ethics is a personal reflection of a Khalifah who works based on his conceptual abilities who are creative and innovative (Azizi, 2005).In this study, the Islamic work ethic used is the Islamic work ethic which is owned by PT. General Takaful Insurance. PT Asuransi Takaful Umum has five dimensions of Islamic work ethics: 1). Itqan, do something perfectly. In language, Itqan means perfect. Whereas in a general sense, Itqan is doing something completely, perfectly, reaching and even exceeding the target, and inviting satisfaction from all parties. 2). Hafidzun Alim, trustful, and professional. Professionals are also used as "Hafidzun Alim". 3). Trust, keep trust. Professionals are used as Amanah (al Amin, which is the root word of Amanah), which means maintaining the trust of what is assigned to them. 4). Al - Kayis, smart, or successful. Professionals are also described in Kayis (smart or successful). 5).Al-Qawiy, have the ability or strength. Professionals are also familiar with Qawiy, which is having strength or ability. What is meant by strength in this hadith is mental strength, soul strength, a strength that can better manage personalities.

\section{METHODOLOGY}

The research method used to support this research is quantitative research supported by data collection techniques with documents. Documents (Sugiyono, 2017) are records of past events. Documents can be in the form of writings, pictures, or monumental works of a person. Document study is a complement to the use of observation and interview methods in quantitative research. According to Sugiyono (2017), Quantitative research methods are research methods based on the philosophy of positivism, used in examining samples and research populations, sampling techniques are generally carried out by random or random sampling. For this reason, the sample used in this study was 50 employees and 10 of them were leaders. To measure Islamic work ethics, a Likert scale is used.

\section{RESULT AND DISCUSSION}

\subsection{Characteristics of Respondents}

The characteristics of respondents in this study were based on gender, division, length of work, and position. As many as $75 \%$ respondents were dominated by men and the remaining $25 \%$ were female respondents. This is because many household heads work and provide for their families by working as one of the employees of PT Asuransi Takaful Umum. Based on the work division, 58\% of respondents were dominated by the marketing department. The marketing department has more divisions and divisions than any other. While the remaining 34\% of respondents came from the technician section 
Lhatifan, et al. Application of Islamic Work Ethics to Employees at PT Asuransi Takaful Umum (Case Study: Head Office Jakarta) and the remaining $8 \%$ came from compliance. Based on the length of work, $50 \%$ of the respondents had worked for more than 5 years, 33\% had worked for more than a year, and the remaining 17\% had worked for less than one year. Based on the position of respondents as much as $90 \%$ are employees while the remaining $10 \%$ are heads of divisions.

\subsection{Analysis of Islamic Work Ethics on Employees}

To become part of an insane takaful, both for employees and directors, the first thing that will be taken is the recruitment process. In this process, prospective takaful individuals will discuss, one of which is the purpose of the prospective takaful employees to join the company. This is necessary because of the difference between Islamic insurance and conventional insurance. Where these differences will lead to new things that prospective tafakul will go through when joining the company later. When a potential takaful person has joined the company, the takaful person must be able to carry out what has become the corporate culture. If a takaful person does not heed the company culture, PT Asuransi Takaful Umum will take steps by providing taushiah and motivation carried out by the HRD department.

\subsubsection{Itqan Factors in Islamic Work Ethics for Employees}

To find out the extent to which the Itqan value of employees of PT Asuransi Takaful generally has been implemented, four indicators are used as benchmarks, namely completing work following the assigned task, completing work not on time, completing tasks due to the burden of responsibility, and doing tasks that exceed the target. determined. The following are the results of weighting regarding the application of Itqan values to employees of PT Asuransi Takaful Umum:

Table 1 Employee Responses to the Implementation of Itqan Principles to employees of PT Asuransi Takaful Umum

\begin{tabular}{|c|c|c|c|c|c|c|c|c|}
\hline \multirow{2}{*}{ No. } & \multirow{2}{*}{ Statement } & \multicolumn{5}{|c|}{ Statement Frequency } & \multirow{2}{*}{$\begin{array}{l}\text { Score } \\
\text { Score }\end{array}$} & \multirow{2}{*}{$\begin{array}{c}\text { Interpretation } \\
\text { Scale }\end{array}$} \\
\hline & & SS & $\mathbf{S}$ & CS & TS & STS & & \\
\hline 1 & I complete the work according to the assignment given & 28 & 18 & 4 & 0 & 0 & 224 & Strongly agree \\
\hline 2 & I didn't finish work on time & 0 & 0 & 6 & 23 & 21 & 85 & $\begin{array}{l}\text { Strongly } \\
\text { Disagree }\end{array}$ \\
\hline 3 & $\begin{array}{l}\text { I finished assignments because of the burden of } \\
\text { responsibility }\end{array}$ & 9 & 22 & 6 & 7 & 6 & 171 & Agree \\
\hline 4 & I did the task beyond the specified target & 14 & 10 & 8 & 13 & 5 & 165 & Simply Agree \\
\hline & $\begin{array}{c}\text { Average Score } \\
\end{array}$ & & & & & & 161.25 & Simply Agree \\
\hline
\end{tabular}

Source: Researcher Process, 2019

Based on the analysis from Table 1. it can be concluded that:

[1] As many as $100 \%$ of the 50 employees at PT Asuransi Takaful Umum can be declared to have applied the first point of the Itqan value, namely completing work by the assigned task.

[2] As many as $88 \%$ of the 50 employees at PT Asuransi Takaful Umum can be declared to have applied the second point of the Itqan value, namely get the job done on time

[3] As many as $74 \%$ of the 50 employees at PT Asuransi Takaful Umum feel overwhelmed by the tasks given because of the burden of responsibility.

[4] As many as 64\% of the 50 employees at PT Asuransi Takaful Umum can be stated that they have applied the fourth point of the Itqan value, namely completing tasks that exceed the specified target.

With an average score of the Itqan variable of 161.25 (Enough Agree), it means that the employees of PT Asuransi Takaful Umum have implemented enough Itqan values in their work processes. Based on the results of interviews with leaders, the high score on the statement regarding employees completing work by the given task is because the company has provided its employees with the tasks assigned to the employee, which is related or connected with other divisions so that it requires employees to work carefully with tasks that are assigned to them. run. And if employees do not do their job properly, it will have an impact on the employee's performance appraisal and will hinder the performance of the division and downstream from the bad performance which will affect the Tafakul Umum insurance company.

\subsubsection{Hafidzul Alim Factors in Islamic Work Ethics for Employees}

To find out the extent to which the Hafidzul Alim value of employees of PT Asuransi Takaful generally applies, four indicators are used as benchmarks, namely working by their fields and expertise, working using their skills, developing effective and modern methods, and learning new things. for optimal work results. 
Table 2 Employee Responses to The Application of Hafidzul Alim Principles There are employees of PT Asuransi Takaful Umum

\begin{tabular}{|c|c|c|c|c|c|c|c|c|}
\hline \multirow{2}{*}{ No. } & \multirow{2}{*}{ Statement } & \multicolumn{5}{|c|}{ Statement Frequency } & \multirow{2}{*}{$\begin{array}{l}\text { Score } \\
\text { Score }\end{array}$} & \multirow{2}{*}{$\begin{array}{c}\text { Interpretation } \\
\text { Scale }\end{array}$} \\
\hline & & SS & $\mathbf{S}$ & CS & TS & STS & & \\
\hline 1 & I work by their fields and expertise & 18 & 18 & 1 & 9 & 4 & 187 & Agree \\
\hline 2 & I work using the skills I have & 28 & 16 & 2 & 1 & 3 & 215 & Strongly agree \\
\hline 3 & I developed an effective and modern method & 19 & 22 & 8 & 0 & 1 & 208 & Agree \\
\hline 4 & I learn new things for optimal work results & 19 & 25 & 5 & 1 & 0 & 212 & Strongly agree \\
\hline & Average Score & & & & & & 205.5 & Agree \\
\hline
\end{tabular}

Based on the analysis of the table above, it can be concluded that:

[1] As many as $74 \%$ of the 50 employees at PT Asuransi Takaful Umum can be declared to have applied the first point of Hafidzun Allim's value, namely working by their fields and expertise.

[2] As many as $72 \%$ of the 50 employees at PT Asuransi Takaful Umum can be declared to have implemented the second point, namely working using their skills.

[3] As many as $98 \%$ of the 50 employees at PT Asuransi Takaful Umum can be stated that they have applied the third point, namely working by developing effective and modern methods to support their work.

[4] As many as $98 \%$ of the 50 employees at PT Asuransi Takaful Umum can be declared to have applied the fourth point, namely working with learning new things for optimal work results.

With an average score of the Hafidzun Alim variable of 205.5 (Agree), it means that the employees of PT Asuransi Takaful Umum can be declared to have implemented the values of Hafidzun Alim in their work process. Based on the results of interviews with leaders, the high score on statements about employees working using the skills they have is because the company always evaluates the work performance of leaders and employees. So that when one of the employees cannot work according to their skills, the employees will be given direction and guidance so they can understand what they are doing.

\subsubsection{Trust Factors in Islamic Work Ethics for Employees}

To find out the extent to which the implementation of the Amanah value of PT Asuransi Takaful general employees, four indicators are used as benchmarks, namely using office equipment only for work, conveying the truth even though it is less liked by colleagues, being responsible for the work carried out, and not abusing their position for personal gain. The following is the weighting result regarding the application of Amanah value to employees of PT Asuransi Takaful Umum

\section{Table 3 Employee Responses to the Application of Trust Principles to Employees of PT Asuransi Takaful Umum}

\begin{tabular}{lllllllll}
\hline \multirow{2}{*}{ No. } & \multirow{2}{*}{ Statement } & \multicolumn{3}{c}{ Statement Frequency } & Score & Interpretation \\
\cline { 2 - 7 } & SS & S & CS & TS & STS & & Score & Scale \\
\hline 1 & I use office equipment only for work & 9 & 28 & 6 & 4 & 3 & 186 & Agree \\
2 & I tell the truth even though my colleagues don't like it & 22 & 22 & 3 & 1 & 2 & 211 & Strongly agree \\
3 & I am in charge of the work that I carry & 24 & 19 & 7 & 0 & 0 & 217 & Strongly agree \\
4 & I do not abuse my position for personal gain & 34 & 16 & 0 & 0 & 0 & 234 & Strongly agree \\
\hline Average Score & & & & & $\mathbf{2 1 2}$ & Strongly agree \\
\hline
\end{tabular}

Source: Researcher Process, 2019

Based on the analysis of the Table 3, it can be concluded that:

[1] As many as $86 \%$ of the 50 employees at PT Asuransi Takaful Umum can be declared to have applied the first point of the Amanah value, which is to have used office equipment only for work

[2] As many as $94 \%$ of the 50 employees at PT Asuransi Takaful Umum can be declared to have implemented the second point of the Amanah value, which has conveyed the truth even though it is not liked by colleagues.

[3] As many as $100 \%$ of the 50 employees at PT Asuransi Takaful Umum can be declared to have implemented the third point of the Amanah value, which is that they have been responsible for the work they carry.

[4] As many as $100 \%$ of the 50 employees at PT Asuransi Takaful Umum can be declared to have implemented the third point of the Amanah value, which is not to abuse their position for personal gain.

With an average score of the Amanah variable of 212 (Strongly Agree), it means that PT Asuransi Takaful Umum employees can be declared to have implemented Amanah values in their work process. Based on the results of interviews with leaders, the high score for each statement of the Amanah factor is because employees know the foundation of the existing work culture in the company. The company's work culture has been conveyed before employees work for the company. This is very important for employees to know to minimize ineffectiveness at work. 


\subsubsection{Al-Kayis Factors in Islamic Work Ethics for Employees}

To find out the extent to which the implementation of Al-Kayis values from general PT Asuransi Takaful employees, four indicators are used as benchmarks, namely working solely for worship, receiving criticism and suggestions from fellow employees for the progress of the company, and working to get the pleasure of Allah SWT.

Table 4 Employee Responses to the Application of Al-Kayis Principles to Employees of PT Asuransi Takaful Umum

\begin{tabular}{|c|c|c|c|c|c|c|c|c|}
\hline \multirow{2}{*}{ No. } & \multirow{2}{*}{ Statement } & \multicolumn{5}{|c|}{ Statement Frequency } & \multirow{2}{*}{$\begin{array}{l}\text { Score } \\
\text { Score }\end{array}$} & \multirow{2}{*}{$\begin{array}{l}\text { Interpretation } \\
\text { Scale }\end{array}$} \\
\hline & & SS & $\mathbf{S}$ & $\mathbf{C S}$ & TS & STS & & \\
\hline 1 & I work solely for worship & 24 & 20 & 6 & 0 & 0 & 218 & Strongly agree \\
\hline 2 & $\begin{array}{l}\text { I accept criticism and suggestions from fellow employees } \\
\text { for the betterment of the company }\end{array}$ & 32 & 14 & 4 & 0 & 0 & 228 & Strongly agree \\
\hline 3 & I sometimes make mistakes that can hurt the company & 0 & 0 & 10 & 20 & 20 & 90 & Disagree \\
\hline 4 & I am working to get Ridha Allah SWT & 38 & 12 & 0 & 0 & 0 & 238 & Strongly agree \\
\hline \multicolumn{2}{|r|}{ Average Score } & & & & & & 193.5 & Agree \\
\hline
\end{tabular}

Source: Researcher Process, 2019.

Based on the analysis from Table 4 it can be concluded that:

[1] As many as $100 \%$ of the 50 employees at PT Asuransi Takaful Umum can be declared to have applied the first point of the Al-Kayis value, which is that they have worked solely for worship. As many as $92 \%$ of the 50 employees at PT Asuransi Takaful Umum can be declared to have applied the second point is the value of Amanah, which is to convey the truth even though it is less liked by colleagues

[2] As many as $100 \%$ of the 50 employees at PT Asuransi Takaful Umum can be declared to have applied the second point of the Al-Kayis value, namely accept criticism and suggestions from friends - employees for the progress of the company.

[3] As many as $80 \%$ of the 50 employees at PT Asuransi Takaful Umum have applied the third point of the Al-Kayis value, which is not making mistakes that can harm the company,

[4] As many as $100 \%$ of the 50 employees at PT Asuransi Takaful Umum have applied the fourth point of the Al-Kayis value, namely working to get Ridha Allah SWT.

With the variable score average $A l$ - Kayisamounting to 193.5 (Agree), meaning that employees of PT Asuransi Takaful Umum can be declared to have implemented Al-Kayis values in their work process. Based on the results of interviews with leaders, the small score is on the statement that employees sometimes make mistakes that can harm the company because employees already know the purpose of establishing the company. This can minimize any losses that will be experienced by the company and its employees

\subsubsection{Al - Qawiy Factors in Islamic Work Ethics for Employees}

To find out the extent to which the implementation of the Al-Qawiy value of the employees of PT Asuransi Takaful general, four indicators are used as benchmarks, namely working with less enthusiasm, working seriously, working with confidence in their abilities, and feeling that the assignment given is a burden.

Table 5 Employee Responses to the Implementation of Al-Qawiy Principles to employees of PT Asuransi Takaful Umum

\begin{tabular}{clcccccccc}
\hline \multirow{2}{*}{ No. } & \multirow{2}{*}{ Statement } & \multicolumn{3}{c}{ Statement Frequency } & Score & Interpretation \\
\cline { 3 - 7 } & SS & S & CS & TS & STS & Score & Scale \\
\hline 1 & I sometimes work with a lack of enthusiasm & 1 & 11 & 8 & 18 & 12 & 121 & Disagree \\
2 & I work earnestly & 29 & 21 & 0 & 0 & 0 & 229 & Strongly agree \\
3 & I work with confidence in my abilities & 28 & 21 & 1 & 0 & 0 & 227 & Strongly agree \\
4 & I sometimes feel that the task given is a burden & 2 & 7 & 7 & 15 & 19 & 108 & Disagree \\
\hline \multicolumn{2}{r}{ Average Score } & & & & & $\mathbf{1 7 1 . 2 5}$ & Agree \\
\hline
\end{tabular}

Source: Researcher Process, 2019.

\subsection{Analysis of Islamic Work Ethics on Leaders}

\subsubsection{Itqan Factors in Islamic Work Ethics towards Leaders}

To find out the extent of the application of the Itqan value from the leadership of PT Asuransi Takaful in general, four indicators are used as benchmarks, namely completing work by the given task, completing work not on time, completing tasks due to the burden of responsibility, and doing tasks that exceed the target. determined. 
Table 6 Leadership Responses to the Application of Itqan Principles at PT Asuransi Takaful Umum

\begin{tabular}{|c|c|c|c|c|c|c|c|c|}
\hline \multirow{2}{*}{$\begin{array}{l}\text { No } \\
\text { • }\end{array}$} & \multirow[b]{2}{*}{ Statement } & \multicolumn{5}{|c|}{ Statement Frequency } & \multirow{2}{*}{$\begin{array}{l}\text { Scor } \\
\text { e } \\
\text { Scor } \\
\text { e }\end{array}$} & \multirow{2}{*}{$\begin{array}{l}\text { Interpretation } \\
\text { Scale }\end{array}$} \\
\hline & & SS & $\mathbf{S}$ & CS & TS & STS & & \\
\hline 1 & I complete the work according to the assignment given & 7 & 3 & 0 & 0 & 0 & 47 & Strongly agree \\
\hline 2 & I didn't finish work on time & 0 & 0 & 2 & 4 & 4 & 18 & Strongly Disagree \\
\hline 3 & $\begin{array}{l}\text { I finished assignments because of the burden of } \\
\text { responsibility }\end{array}$ & 3 & 3 & 2 & 0 & 2 & 35 & Agree \\
\hline 4 & I did the task beyond the specified target & 3 & 2 & 1 & 1 & 3 & 31 & Simply Agree \\
\hline \multicolumn{7}{|c|}{ Average Score } & 32.75 & Simply Agree \\
\hline
\end{tabular}

Source: Researcher Process, 2019.

Based on the analysis of the table above, it can be concluded that:

[1] As many as $100 \%$ of the 10 leaders in PT Asuransi Takaful Umum can be declared to have implemented the first point of the Itqan value, namely completing work by the assigned task.

[2] As many as $80 \%$ of the 10 leaders in PT Asuransi Takaful Umum can be declared to have applied the second point of the Itqan value, namely get the job done on time

[3] As many as $80 \%$ of the 10 leaders in PT Asuransi Takaful Umum are stated to feel overwhelmed by the tasks given because of the burden of responsibility

[4] As many as $60 \%$ of the 10 leaders in PT Asuransi Takaful Umum can be declared to have implemented the fourth point of Itqan values, namely completing tasks that exceed the specified target.

With an average score of the Itqan variable of 32.75 (Enough Agree), it means that the leadership of PT Asuransi Takaful Umum has implemented enough Itqan values in their work process.

\subsubsection{Factors of Hafidzun Alim in Islamic Work Ethics towards Leaders}

To find out the extent of the application of the Hafidzul Alim values from the leadership of PT Asuransi Takaful general, four indicators are used as benchmarks, namely working by their fields and expertise, working using their skills, developing effective and modern methods, and learning new things. for optimal work results.

Table 7 Leadership Responses to the Application of Hafidzul Alim Principles at PT Asuransi Takaful Umum

\section{No. Statement}

$1 \quad$ I work by their fields and expertise

2 I work using the skills I have

3 I developed an effective and modern method

$4 \quad$ I learn new things for optimal work results

\begin{tabular}{lllllll}
\multicolumn{4}{l}{ Statement } & Frequency & Score & Interpretation \\
\cline { 1 - 5 } SS & S & CS & TS & STS & Score & Scale \\
4 & 2 & 1 & 2 & 1 & 36 & Agree \\
6 & 2 & 0 & 0 & 2 & 40 & Agree \\
4 & 4 & 1 & 0 & 1 & 40 & Agree \\
4 & 5 & 1 & 0 & 0 & 43 & Strongly agree \\
\hline
\end{tabular}

Average Score

39.75 Agree

Source: Researcher Process, 2019.

Based on the analysis from Table 7 it can be concluded that:

[1] As many as $70 \%$ of the 10 leaders in PT Asuransi Takaful Umum can be declared to have applied the first point of Hafidzun Allim's value, namely working by their fields and expertise.

[2] As many as $80 \%$ of the 10 leaders in PT Asuransi Takaful Umum can be declared to have applied the second point, namely working using their skills

[3] As many as $100 \%$ of the 10 leaders in PT Asuransi Takaful Umum can be declared to have implemented the third point, namely working by developing effective and modern methods to support their work.

[4] As many as $100 \%$ of the 50 employees at PT Asuransi Takaful Umum can be declared to have implemented the fourth point, namely working with learning new things for optimal work results.

With the average score of the Hafidzun Alim variable of 39.75 (Agree), it means that the leadership of PT Asuransi Takaful Umum can be declared as having implemented the values of Hafidzun Alim in their work process.

\subsubsection{Trust Factors in Islamic Work Ethics for Leaders}

To find out the extent of the application of the Amanah value from the leadership of PT Asuransi Takaful in general, four indicators are used as benchmarks, namely using office equipment only for work, conveying the truth even though it is less liked by colleagues, being responsible for the work carried out, and not abusing one's position for personal gain. 
Table 8 Responses from Leaders Against the Application of Amanah Principles at PT Asuransi Takaful Umum

\begin{tabular}{llllllllll}
\hline \multirow{2}{*}{ No. } & Statement & \multicolumn{3}{c}{ Statement Frequency } & Score & Interpretation \\
\cline { 2 - 7 } & SS & S & CS & TS & STS & Score & Scale \\
\hline 1 & I use office equipment only for work & 2 & 5 & 1 & 1 & 1 & 36 & Agree \\
2 & I tell the truth even though my colleagues don't like it & 5 & 3 & 2 & 0 & 0 & 43 & Strongly agree \\
3 & I am in charge of the work that I carry & 5 & 4 & 1 & 0 & 0 & 44 & Strongly agree \\
4 & I do not abuse my position for personal gain & 6 & 4 & 0 & 0 & 0 & 46 & Strongly agree \\
\hline
\end{tabular}

Average Score

42.25 Strongly agree

Source: Researcher Process, 2019.

Based on the analysis of Table 8, it can be concluded that:

[1] As many as $80 \%$ of the 10 leaders in PT Asuransi Takaful Umum can be declared to have implemented the first point of the Amanah value, which is to have used office equipment only for work

[2] As many as $100 \%$ of the 10 leaders in PT Asuransi Takaful Umum can be declared to have implemented the second point of the Amanah value, which has conveyed the truth even though it is not liked by colleagues

[3] As many as $100 \%$ of the 10 leaders in PT Asuransi Takaful Umum can be declared to have implemented the third point of the Amanah value, which is that they have been responsible for the work they carry.

[4] As many as $100 \%$ of the 10 leaders in PT Asuransi Takaful Umum can be declared to have applied the third point of the Amanah value, which is not to abuse their position for personal gain.

With an average score of the Amanah variable of 42.25 (Strongly Agree), it means that the leadership of PT Asuransi Takaful Umum can be declared to have implemented Amanah values in their work process.

\subsubsection{Al-Kayis Factors in Islamic Work Ethics for Leaders}

To find out the extent of the application of Al-Kayis values from the leadership of PT Asuransi Takaful general, four indicators are used as benchmarks, namely working solely for worship, receiving criticism and suggestions from fellow employees for the progress of the company, and working to get the pleasure of Allah. SWT. The following are the results of weighting regarding the application of Al-Kayis values to employees of PT Asuransi Takaful Umum.

Table 9 Leadership Responses to the Application of the Principles of Al-Kayis at PT Asuransi Takaful Umum

\begin{tabular}{llcccccccc}
\hline \multirow{2}{*}{ No. Statement } & \multicolumn{3}{c}{ Statement Frequency } & Score & Interpretation \\
\cline { 2 - 7 } & SS & S & CS & TS & STS & Score & Scale \\
\hline 1 & $\begin{array}{l}\text { I work solely for worship } \\
2\end{array}$ & $\begin{array}{l}\text { I accept criticism and suggestions from fellow employees } \\
\text { for the betterment of the company }\end{array}$ & 6 & 2 & 2 & 0 & 0 & 44 & Strongly agree \\
3 & $\begin{array}{l}\text { I sometimes make mistakes that can hurt the company } \\
4\end{array}$ & 0 & 0 & 1 & 5 & 4 & 17 & Strongly Disagree \\
4 & I am working to get Ridha Allah SWT & 7 & 3 & 0 & 0 & 0 & 47 & Strongly agree \\
\hline Average Score & & & & & & $\mathbf{3 8 . 5}$ & Agree \\
\hline
\end{tabular}

Source: Researcher Process, 2019.

Based on the analysis from Table 9 it can be concluded that:

[1] As many as $100 \%$ of the 10 leaders in PT Asuransi Takaful Umum can be declared to have implemented the first point of Al-Kayis value, which is that they have worked solely for worship.

[2] As many as $100 \%$ of the 10 leaders in PT Asuransi Takaful Umum can be declared to have implemented the second point of Al-Kayis values, namely receiving criticism and suggestions from employee friends for the progress of the company.

[3] As many as $90 \%$ of the 10 leaders in PT Asuransi Takaful Umum are declared to have applied the third point of the Al-Kayis value, namely not make mistakes that can harm the company,

[4] As many as $100 \%$ of the 10 leaders in PT Asuransi Takaful Umum have applied the fourth point of the Al-Kayis value, namely working to get Ridha Allah SWT.

With an average score of the Al-Kayis variable of 42.25 (Strongly Agree), it means that the leadership of PT Asuransi Takaful Umum has implemented Al-Kayis values in their work process. Based on the results of interviews with leaders, the company has a morning sharing program that is conducted once a week to evaluate current conditions. In 
Lhatifan, et al. Application of Islamic Work Ethics to Employees at PT Asuransi Takaful Umum (Case Study: Head Office Jakarta) practice, this morning sharing brings together directors and subordinates. This morning sharing is a place for directors to hear complaints from their subordinates or discuss issues that are hotly discussed within the Tafakul Umum insurance company. Besides, the company also conducts scheduled briefings once a month to motivate employees in Tafakul Umum insurance.

\subsubsection{Al - Qawiy Factors in Islamic Work Ethics towards Leaders}

To find out the extent to which the implementation of Al-Qawiy values from the leadership of PT Asuransi Takaful general, four indicators are used as benchmarks, namely working with less enthusiasm, working seriously, working with confidence in one's abilities, and feeling that the assignment given is a burden. . The following are the results of weighting regarding the application of Al-Qawiy values to employees of PT Asuransi Takaful Umum:

Table 10 Leadership Responses to the Application of Al-Qawiy Principles at PT Asuransi Takaful Umum

\begin{tabular}{lllllllll}
\multirow{2}{*}{ No. } & Statement & \multicolumn{3}{c}{ Statement } & Frequency & Score & Interpretation \\
\cline { 3 - 6 } & & SS & S & CS & TS & STS & Score & Scale \\
\hline 1 & I sometimes work with a lack of enthusiasm & 0 & 1 & 3 & 4 & 2 & 23 & Disagree \\
2 & I work earnestly & 6 & 4 & 0 & 0 & 0 & 46 & Strongly agree \\
3 & I work with confidence in my abilities & 7 & 3 & 0 & 0 & 0 & 47 & Strongly agree \\
4 & I sometimes feel that the task given is a burden & 0 & 0 & 3 & 3 & 4 & 19 & Disagree \\
\hline Average Score & & & & & $\mathbf{3 3 . 7 5}$ & Simply Agree
\end{tabular}

Source: Researcher Process, 2019.

Based on the analysis from Table 10 it can be concluded that:

[1] As many as $60 \%$ of the 10 leaders in PT Asuransi Takaful Umum can be declared to have applied the first point of the Al-Qawiy value, which is to have worked with enthusiasm, and the remaining $40 \%$ cannot be declared to have applied the first point of the Al-Qawiy value

[2] As many as $100 \%$ of the 10 leaders in PT Asuransi Takaful Umum can be declared to have implemented the second point of the Al-Qawiy value, which is to have worked seriously.

[3] As many as $100 \%$ of the 10 leaders in PT Asuransi Takaful Umum can be declared to have applied the third point of the Al-Qawiy value, which is to have worked confidently in their abilities.

[4] As many as 70\% of the 10 leaders in PT Asuransi Takaful Umum can be stated that they have applied the fourth point of the Al-Qawiy value, which is that they have worked without feeling overwhelmed by the assigned task.

With the variable score average $\mathrm{Al}$ - Qawiy amounting to 33.75 (Enough Agree), meaning that the leadership of PT Asuransi Takaful Umum can be declared as having sufficiently implemented the values of Al - Qawiy in their work process.

\section{CONCLUSIONS}

The results of research conducted regarding the Application of Islamic Work Ethics to Employees at PT Asuransi Takaful Umum are 1) Dwight an average score of the Itqan variable for employees of 161.25 (Enough Agree) and the leadership of 32.75 (quite agree), it means that the employees and leaders of PT Asuransi Takaful Umum have sufficiently implemented Itqan values in their work processes. According to the results of the interview, prospective takaful people are required to be able to understand what they are doing, be it, employees or leaders. This is because of the performance of one takaful insan is hampered, it can interfere with his part, then continues in his division. So that it can disrupt the company; 2)With the average score of the Hafidzun Alim variable of 205.5 (Agree) and the leadership of 39.75 (agree), it means that the employees and leaders of PT Asuransi Takaful Umum can be declared to have implemented the values of Hafidzun Alim in their work process. According to the results of the interview, the takaful candidates are always evaluated every month, so that the takaful people are indirectly required to be able to do their job well. By developing every potential that exists, takaful people can have a high sense of professionalism and feel entrusted to be able to understand the work assigned. With an average score of the Amanah variable of 212 (Strongly Agree) and the leader of 42.25 (strongly agree) means that employees of PT Asuransi Takaful Umum can be declared to have implemented Amanah values in their work process. According to the results of the interview, the prospective takaful workers were introduced to the company regarding the existing work culture. Besides, the company explains what is the basis of the company's work culture, one of which is the nature of the Prophet Muhammad, namely the nature of trust. Where the nature of this mandate is one of the moral beliefs. Allah SWT said that the characteristics of the lucky believers are those who can maintain the trust given to them. where one of them is the nature of Rasullullah SAW, namely the nature of trust. Where the nature of this mandate is one of the moral beliefs. Allah SWT said that the characteristics of the lucky believers are those who can maintain the trust given to them. where one of them is the nature of Rasullullah SAW, namely the nature of trust. Where the nature of this mandate is one of the moral beliefs. Allah SWT said that the characteristics of the lucky believers are those who can maintain the trust given to them. With the variable score average $A l$ - Kayisamounting to 193.5 (Agree) and the leadership of 42.25 (strongly agree) means that the employees of PT Asuransi Takaful Umum can be declared to have implemented the values of Al- 
Kayis in their work process. According to the results of the interview, takaful employees are required to have one vision and mission with the company, so that unwanted things do not occur that are detrimental to the company. So that takaful people must have evaluative and visionary characteristics. With the variable score average $A l$ - Qawiyamounting to 171.25 (Agree) and the leadership 33.75 (quite agree) means that the employees and leaders of PT Asuransi Takaful Umum can be declared to have implemented the values of Al - Qawiy in their work process. According to the results of the interview, one of the work cultures in the company is professional. Where takaful people are required to have strength and expertise in managing something. So that every form of problem that occurs in the company can be resolved properly.

\section{ACKNOWLEDGMENT}

The author would like to thank Bandung Islamic University which has become the place where the author carries out his knowledge. The author also thanks everyone willing to provide assistance and willingness in helping the author complete this research

\section{REFERENCES}

Azizi, Ali M. 2005. Dakwah Pemberdayaan Masyarakat: Paradikma Aksi Metodologi, Yogyakarta: Pustaka Pesantren Amaliah, Ima, Aan Julia, Riani, Westi. 2013. "Pengaruh Nilai Islam terhadap Kinerja Kerja". Mimbar: Jurnal Sosial dan Pembangunan. Vol.29.No.2 Desember 2013: 165-174, Bandung, LPPM Unisba.

Hidayat, Iman. 2006. "Etos Kerja Sesuai dengan Etika Profesi Islam”. Mimbar Jurnal Sosial dan Pembangunan. Vol XXII No.1 Bandung. P2U: LPPMUnisba

Lathifan P, Lulu. 2020. “Etika Kerja Islami PT Asuransi Takaful Umum”. Hasil Wawancara Pribadi. 13 Maret 2020 , Universitas Islam Bandung

Lifepal.co.id/asuransi/takaful-umum/\#

Peraturan Otoritas Jasa Keuangan Nomor 72 /Pojk.05/2016 Tentang Kesehatan Keuangan Perusahaan Asuransi dan Perusahaan Reasuransi Dengan Prinsip Syariah

Sugiyono. 2017. Metode Penelitian Kuantitatiuf, Kualitatif, dan R\&D. Bandung: Alfabeta, CV.

Tasmara, Toto. 1995. Etos Kerja Pribadi Muslim. Jakarta: PT Dana Bhakti Wakaf

Takafulumum.co.id/beranda

Takafulumum.co.id/produk-asuransi-syariah

Takafulumum.co.id/literasi 